\title{
Individual Effective Dose and Nuclear Emergency Planning for Muntok NPP Area using TMI-2 Source Term
}

\author{
Sunarko*1, Zaki Suud ${ }^{2}$ \\ 1, Nuclear Energy System Assessment, BATAN, JI Kuningan Barat Mampang Prapatan, Jakarta, Indonesia \\ 2, Physics Department, Institut Teknologi Bandung, Jl. Ganesha 10, Bandung, Indonesia
}

\begin{tabular}{l}
\hline ARTICLE INFORMATION \\
\hline Article History: \\
Submitted: \\
21 June 2020 \\
Received in revised: \\
10 October 2020 \\
Approved: \\
13 October 2020
\end{tabular}

Keywords:

Effective dose

Probabilistic assessment

LPDM

LOCA

\begin{abstract}
INDIVIDUAL EFFECTIVE DOSE AND NUCLEAR EMERGENCY PLANNING FOR MUNTOK NPP AREA USING TMI-2 SOURCE TERM. Probabilistic dose analysis from a postulated nuclear accident is performed for the Muntok area in the western Bangka region. Three-Mile Island unit 2PWR-type Nuclear Power Plant (TMI-2) source-term is compiled and used as accident data. The accident is also known as the Small-break Loss of Coolant Accident (SB-LOCA) accident. The isotopes used in the simulation are $\mathrm{Kr}-88, \mathrm{l}-131, \mathrm{Xe}-133$, and $\mathrm{Cs}-137$. The release point is a $50 \mathrm{~m}$ stack. Lagrangian particle dispersion method (LPDM) is used along with a 3-dimensional massconsistent wind-field. Surface-level time-integrated air concentration and spatial distribution of ground-level total dose were obtained for dry conditions. Meteorological data is taken from hourly records obtained from an on-site meteorological tower in Muntok area for the 2014-2015 period. Effluent is released at a uniform rate during a 6-hour period and the dose is integrated for 12 hours from the beginning of the release until most of the plume left the model boundaries. The regulatory limit for the general public of $1 \mathrm{mSv}$ was detected in an area located $2.5 \mathrm{~km}$ from the release point. Radioactive plume is spread from the postulated plant location to uninhabited areas consisted of bushes and farming areas in the SE-SSE direction and to W-NW direction to the Bangka Sea.
\end{abstract}

\begin{abstract}
ABSTRAK
DOSIS INDIVIDU EFEKTIF DAN PENANGGULANGAN KEDARURATAN NUKLIR DI DAERAH PLTN MUNTOK MENGGUNAKAN SUKU-SUMBER TMI-2. Kajian dosis probabilistik dilakukan untuk kondisi kecelakaan radioaktif di daerah Munto di daerah Bangka Barat. Suku-sumber yang digunakan diperoleh dari data kecelakaan Small-break Loss of Coolant Accident (SB-LOCA) Pembangkit Listrik Tenaga Nuklir (PLTN) jenis air bertekanan (PWR) Three-Mile Island unit 2 (TMI-2). Isotop utama yang digunakan dalam simulasi adalah Kr-88, I-131, Xe-133 and Cs-137. Lepasan radioaktif diasumsikan berasal dari cerobong berketinggian $50 \mathrm{~m}$. Metode dispersi partikel Lagrangian (MDPL) dalam medan-angin 3-dimensi berdasarkan model konsisten masa digunakan untuk mendapatkan konsentrasi udara terintegrasi pada lapisan permukaan dan distribusi spasial dari dosis total pada kondisi kering. Data meteorologi spesifik tapak diperoleh dari rekaman per-jam pada saat dilakukan Studi Kelayakan PLTN di Muntok pada periode 20142015. Efluen dilepaskan dengan laju seragam dalam periode 6-jam dan dosis diintegrasikan dalam waktu 12 jam sejak lepasan pertama hingga semua efluen telah melampaui batas pemodelan. Dosis maksimum terhitung melebihi batas regulasi $1 \mathrm{mSv}$ terdeteksi dalam $2,5 \mathrm{~km}$ radius dari titik lepasan dan kepulan radioaktif sebagian besar terdispersi ke daerah tidak berpenduduk tetap yang terdiri dari semak dan lahan perkebunan ke arah Tenggara-Selatan Tenggara serta Barat - Barat Laut dari asumsi lokasi PLTN ke arah Laut Bangka.
\end{abstract}

Kata kunci : dosis efektif, kajian probabilistik, LPDM, LOCA.

\section{INTRODUCTION}

Analysis to provide dose estimation for radioactive dispersion from a postulated accident from a nuclear facility is important to support emergency planning activities and to protect the public from harmful effect of ionizing radiation. The information contained in

\footnotetext{
* Penulis korespondensi.
}

E-mail: sunarko@batan.go.id this analysis is beneficial for emergency response planning, radiation protection activities, as well as nuclear power plant siting and design.

The computer code used in the calculation was developed based on the Lagrangian Particle Dispersion Method (LPDM)[1]. The code can accommodate spatial and temporal variation reflected in the 
input data for topography, wind parameters and source-term. The inputs for this code consists of source-term topographic condition, and wind data which normally be available during the site study phase either through survey, on-site monitoring or from secondary data source.

Three-Mile Island unit-2, referred to as TMI-2, nuclear power plant accident was designated a scale-5 in the International Nuclear Event Scale (INES). It occurred on March 28, 1979. This accident caused some parts of the reactor core to melt and some amount of radioactive release to the environment. It was considered as the most serious accident by the Nuclear Regulatory Committee in the U.S. history of commercial nuclear power plant operation. The initiating event was a loss of feed water that resulted in the increase in the secondary system and turbine pressure, causing the main feed water pump to trip. This caused the pressurizer pilot operated relief valve (PORV) to open and the reactor scrammed. In later sequence, the PORV valve failed to close when the pressure has decreased and initiated a small-break loss-ofcoolant accident (SB-LOCA). Core cooling then performed using forced circulation by coolant pumps but eventually, the pumps tripped due to the presence of voids [3]. Part of the core was melted and fission products were released from the core to the primary containment and then transferred to the auxiliary building by way of the Makeup and Purification System. Outgassing of the cooling water has released fission product gasses to the auxiliary building HVAC system and caused environmental release of radioiodine and noble gasses.

The released amount of radioactivity to the atmosphere has been discussed in several papers [3, 4, 5, 6] for isotopes such as I-131, Cs-137, Kr-88 and Xe-133. The source-term strength rate discussed in the papers has been compiled in the previous study[7] and presented in Table 1.
Previous atmospheric radioactive dispersion study for Muntok area was performed during NPP Siting Project[8] using three postulated accident scenarios: reactivity insertion, loss-of-coolant accident (LOCA), and steam-generator tube rupture (SGTR) while using meteorological data of less than one year duration, which was from January to August 2012. This study is mainly aimed to complement the result from the previous NPP Siting Project using published source-term data from TMI-2 SB-LOCA accident and a more extensive meteorological database (2014-2015). This paper does not attempt direct comparison with the result from NPP Siting Project because of the differences in the method, computer code, source-term strength and extent of meteorological database.

\section{LAGRANGIAN DISPERSION METHOD}

PARTICLE

The Concentration of radionuclides in the environment is modeled based on the advection-diffusion equation (1). A numerical solution was attempted using random-walk Lagrangian Particle Dispersion Method (LPDM). This method can model spatial variation of wind speed and direction, topography and diffusion coefficient in 3dimensional Cartesian coordinate, the advection-diffusion equation uses empirical dispersion coefficient. The description of the model is given as equation 1 [7].

$$
\begin{aligned}
\frac{\partial \bar{C}}{\partial t}=- & \bar{u} \frac{\partial \bar{C}}{\partial x}-\bar{v} \frac{\partial \bar{C}}{\partial y}-\bar{w} \frac{\partial \bar{C}}{\partial z}+\frac{\partial}{\partial x}\left(K_{x} \frac{\partial \bar{C}}{\partial x}\right) \\
+ & \frac{\partial}{\partial y}\left(K_{y} \frac{\partial \bar{C}}{\partial y}\right)+\frac{\partial}{\partial z}\left(K_{z} \frac{\partial \bar{C}}{\partial z}\right) \\
& +w_{s} \frac{\partial \bar{C}}{\partial z}-\Lambda \bar{C}-\lambda \bar{C}+Q
\end{aligned}
$$

\begin{tabular}{|c|c|c|c|c|c|}
\hline \multicolumn{6}{|c|}{ Source strength rate $(\mathrm{Bq} / \mathrm{sec})$} \\
\hline Radionuclide & $\begin{array}{c}\text { Haste et al. } \\
(2006)\end{array}$ & $\begin{array}{l}\text { McColl et al. } \\
(2002)\end{array}$ & $\begin{array}{c}\text { Gudiksen and } \\
\text { Dickerson (1990) }\end{array}$ & US-NRC (1979) & Max. \\
\hline Cs -137 & $2.27 \mathrm{E}+04$ & - & - & - & $2.27 \mathrm{E}+04$ \\
\hline $\mathrm{I}-131$ & $3.12 \mathrm{E}+07$ & $2.31 \mathrm{E}+07$ & $2.40 \mathrm{E}+07$ & - & $3.12 \mathrm{E}+07$ \\
\hline $\mathrm{Kr}-88$ & - & $1.06 \mathrm{E}+08$ & - & - & $1.06 \mathrm{E}+08$ \\
\hline $\mathrm{Xe}-133$ & - & $1.44 \mathrm{E}+10$ & $4.11 \mathrm{E}+12$ & $4.28 \mathrm{E}+12$ & $4.28 \mathrm{E}+12$ \\
\hline
\end{tabular}

Table 1. Source Term 
Concentration $\overline{\mathrm{C}}$ depicts the average concentration while parameters $\overline{\mathrm{u}}, \overline{\mathrm{v}}, \overline{\mathrm{w}}$ are wind components in $\mathrm{x}, \mathrm{y}, \mathrm{z}$ directions, $\mathrm{K}_{\mathrm{x}}, \mathrm{K}_{\mathrm{y}}, \mathrm{K}_{\mathrm{z}}$ are empirical turbulent diffusion coefficients in $\mathrm{x}, \mathrm{y}, \mathrm{z}$ directions. The Gravitational settling process is represented by settling velocity $\mathrm{w}_{\mathrm{s}}$. The Depletion process uses $\Lambda$ as the depletion coefficient, the Decay constant $\lambda$ is used for radioactive decay process and $\mathbf{Q}$ is the sourceterm. In this paper, no gravitational settling, depletion and decay are assumed due to the nature of the effluent which is gaseous and having a long half-time.

Atmospheric turbulence is a stochastic process and there has been many published approaches. In the stochastic approach, particles are used to represent effluent which undergo the advection-diffusion process and experiencing random movement representing turbulent process at the same time. The Average distribution of particles can be obtained by averaging particle paths. Because every particle moves independently, in the computer model, simultaneous handling of particles is not necessary, thus using less computer memory.

LPDM is a model involving a number of particles undergoing advection-diffusion process in a 3-D wind field. LPDM is represented by a stochastic differential equation which describes the process of advection and diffusion in the Lagrangian framework[1]. The equations for the movement of ideal fluid in three-dimension are:

$$
\begin{gathered}
d x_{i}=\bar{u} d t+\left(2 K_{x}\right)^{\frac{1}{2}} d W_{x} \\
d y_{i}=\bar{v} d t+\left(2 K_{y}\right)^{\frac{1}{2}} d W_{y} \\
d z_{i}=\bar{w} d t+\left(2 K_{z}\right)^{\frac{1}{2}} d W_{z}+\frac{\partial K_{z}}{\partial z}
\end{gathered}
$$

Random numbers $\mathrm{dW}_{\mathrm{x}, \mathrm{y}, \mathrm{z}}$ have zero average and variance $d t$, namely $d \bar{W}=0$ and $\mathrm{d} \overline{\mathrm{W}}^{2}=\mathrm{dt}$. Turbulence is assumed to be homogeneous in $\mathrm{x}$ and $\mathrm{y}$ directionsin equation (2) and (3). Integration with respect to time on above equations can be performed to obtain particle paths which represent the movement of each individual particle. In the dispersion simulation, the number of released particle is large and each particle has its own label and certain characteristics such as mass or radioactivity. Concentration at time $\mathrm{t}$ can be identified using particle locations and characteristics.

The implementation of the random-walk method for vertical direction using equation (5)[2]. The height of a particle after one time step $z_{i+1}$ is a summation of four terms, namely the initial height of the particle $\mathbf{z}_{\mathbf{i}}$, movement by wind as $\overline{\mathrm{w}} \Delta \mathrm{t}$, average diffusive movement $\Delta \mathrm{z}_{\mathrm{i}}^{*}$ and random diffusive movement $\Delta \mathrm{z}_{\mathrm{i}}^{\prime}$ as follows:

$$
z_{i+1}=z_{i}+\bar{w} \Delta t+\Delta z_{i}^{*}+\Delta z_{i}^{\prime}
$$

Average diffusive movement is as follows:

$$
\Delta z_{i}^{*}=\left(\frac{\partial K_{z}}{\partial z}\right)_{i} \Delta t_{i}
$$

The Random diffusive movement has the following average and variance:

$$
\begin{gathered}
\left\langle\Delta z_{i}^{\prime}\right\rangle=0 \\
\left\langle\Delta z_{i}^{\prime 2}\right\rangle=2 K_{z i} \Delta t_{i}+\left(\frac{\partial K_{z}}{\partial z}\right)^{2} \Delta t_{i}^{2} \equiv \sigma_{z i}^{2}
\end{gathered}
$$

Random diffusive movement $\Delta z_{i}^{\prime}$ is facilitated using the following uniform distribution function:

$$
\mathrm{P}\left(\Delta \mathrm{z}_{\mathrm{i}}^{\prime}\right)=\left\{\begin{array}{cc}
\frac{1}{2 \sqrt{3} \sigma_{\mathrm{zi}}} & \text { if }-\sqrt{3} \sigma_{\mathrm{zi}}<\Delta \mathrm{z}_{\mathrm{i}}^{\prime}<\sqrt{3} \sigma_{\mathrm{zi}} \\
0 & \text { others }
\end{array}\right.
$$

Hence random diffusive movement $\Delta z_{i}^{\prime}$ is given by:

$$
\Delta z_{i}^{\prime}=2 \sqrt{3} \sigma_{z i}(r-0.5)
$$

Random number $\mathrm{r}$ is obtained from a Marsenne-Twister pseudorandom number generator with a range of $(0,1)$. The equation for horizontal direction has similar form with equation (5) but without the differential form of eddy diffusivity.

The Vertical dispersion coefficient is represented by the following equation for unstable and stable conditions respectively in equation (13) and (14)[9].

$$
K_{z}=0.1 u_{*} h\left|\frac{h}{k L}\right|^{\frac{1}{3}} \sin \left[\frac{\left(\frac{z}{h}+0.5\right) \pi}{2}\right] \times\left[1-\exp \left(-\frac{4 z}{h}\right)-0.0003 \exp \left(\frac{8 z}{h}\right)\right]
$$




$$
K_{z}=0.065 u_{*} h\left(\frac{z}{h}\right)^{\frac{2}{3}}\left[1-\left(\frac{z}{h}\right)^{\frac{2}{3}}\right]^{\frac{1}{2}}
$$

The Horizontal dispersion coefficient for unstable and stable condition is given in equation (15) and (16)[9] respectively.

$$
\begin{gathered}
K_{H}=0.13 u_{*} h\left[12+0.5\left|\frac{h}{l}\right|\right]^{\frac{1}{3}} \\
K_{H}=0.14 u_{*} h\left(\frac{z}{h}\right)^{\frac{1}{2}}\left[1-\left(\frac{z}{h}\right)^{\frac{1}{2}}\right]^{\frac{1}{2}}
\end{gathered}
$$

In the above equations, $\mathrm{h}$ represents the boundary layer thickness andL is the MoninObukhov length. The value for $\mathbf{u}_{*}$ is determined based on surface roughness. $\mathrm{L}$ can be found for Pasquill stability class A-F using equation (17)[10] and the coefficients $\mathrm{a}$ and $\mathrm{b}$ are provided in Table 2.

$$
\frac{1}{L}=a+b \log z_{0}
$$

Table 2. Coefficients for Monin-Obukhov Length[10]

\begin{tabular}{cccc}
\hline $\begin{array}{c}\text { Pasquill } \\
\text { Stability } \\
\text { class }\end{array}$ & \multicolumn{2}{c}{ Coefficient } & Description \\
\hline A & a & b & \\
B & $-0,096$ & 0,029 & Highly unstable \\
C & $-0,002$ & 0,029 & Unstable \\
D & 0 & 0,018 & Slightly unstable \\
E & $+0,004$ & $-0,018$ & Neutral \\
F & $+0,035$ & $-0,036$ & Slightly stable \\
\hline
\end{tabular}

Because Muntok area is situated in a rubber and kernel oil plantation area, the value for $_{0}$ is assumed to be 1 (tree-covered surface).

In the case of neutral atmospheric condition, diffusion coefficients for stable condition can be used[9].

Time-integrated air concentration (TIAC) is obtained by summation of concentration which is calculated after every time integration step for the whole of integration period. In this paper, integration is performed every specified period of time. Concentration is calculated using kernel density estimator for each grid point using particle information in the lowest layer of atmosphere where human beings are mostly affected.

The Wind field is calculated based on mass consistent model[11] to provide wind vectors $(\overline{\mathrm{u}}, \overline{\mathrm{v}}, \overline{\mathrm{w}})$ in a 3 -dimensional Cartesian grid having horizontal intervals $\Delta \mathrm{x}$ and $\Delta \mathrm{y}$ and vertical interval $\Delta \mathrm{z}$. Block topography is provided using data from ground elevation survey or Geographical Information System data. Initial vertical and horizontal wind vector is provided by the Muntok metrological station data and wind-field calculations are performed until convergence is reached. Initial vertical wind distribution is provided by the power law formula[11] in equation 18 .

$$
u=u_{0}\left(\frac{Z}{z_{0}}\right)^{p}
$$

The exponent $\mathbf{p}$ is derived from Table 3 taking into account atmospheric stability and terrain condition.

Table 3. Exponent for Wind-Speed Profile[11]

\begin{tabular}{ccc}
\hline $\begin{array}{c}\text { Stability } \\
\text { category }\end{array}$ & $\begin{array}{c}\text { Village } \\
\text { exponent }\end{array}$ & Urban exponent \\
\hline$A$ & 0.07 & 0.15 \\
$B$ & 0.07 & 0.15 \\
$C$ & 0.10 & 0.20 \\
$D$ & 0.15 & 0.25 \\
$E$ & 0.35 & 0.30 \\
$F$ & 0.55 & 0.30 \\
\hline
\end{tabular}

The effect of rain on dose is not simulated because it was demonstrated in a deterministic analysis that the effect of constant rain with intensities between $5-20$ $\mathrm{mm} /$ hour for a total duration of 6 hours caused only small increase to dose with unnoticeable change in dispersion pattern at the surface layer of the atmosphere from the release of radioiodine and noble gasses[13].

\section{METEOROLOGICAL DATA}

Wind data is obtained from an on-site meteorological station located in the Air Putih village, Muntok District, West Bangka Regency in Bangka Belitung province. The total duration of the data is around 2 years (January 2014 to December 2015), collected during the Site Feasibility Study period. The coordinate of the station is $105.11997^{\circ} /-2.01551^{\circ}$ (Easting 513341.463 meter, Northing 9777224.173 meter, WGS84 Zone 48M)[14]. The data is composed of, among other, temperature at the heights of 10 and 80 meters, wind speed and wind direction at 10 meter height. Data is averaged and logged every hour. In this study, 
atmospheric stability class is determined using temperature data using lapse-rate method.

\section{METHODOLOGY}

A computer code was written to perform the LPDM analysis[15]. Input data includes wind and temperature data, source-term strength, surface roughness and topography around the site. Prognostic wind-field in Cartesian grid is calculated using massconsistent method utilizing 1-station meteorological data for a volume dimension of $100 \mathrm{~km} \times 100 \mathrm{~km} \times 1.5 \mathrm{~km}$ (width, length and height respectively). Radioactive plume with an emission rate of 18,000 particles per hour is used in the model. Kernel density estimator is used to calculate concentrations at grid points for the lowest layer of the atmosphere with a 5 meter thickness. Time-integrated air concentration (TIAC) is obtained and then converted to dose using tabulated conversion factor[16]. Time integration interval in this case is 150 seconds.

The probability of upper-limit dose for a specific release scenario can be mapped to provide a contour of probability for exceeding a certain dose limit. The limit may be in form of regulatory or any other desired limit. The resulting map describes the probability of attaining or exceeding a certain dose limit around a facility based on a certain release condition $\quad \mathrm{P}[\mathrm{D}(\mathrm{x}, \mathrm{y}) \geq$ dose limit|release $]$. The Release parameter is deterministic. $\mathrm{D}(\mathrm{x}, \mathrm{y})$ is the dose received at surface coordinate $(x, y)$. For a number of wind profiles $\mathrm{N}_{\mathrm{w}}$ the probability $\mathrm{P}(\mathrm{x}, \mathrm{y})$ at node $(\mathrm{x}, \mathrm{y})$ is determined by [17]:

$$
\begin{gathered}
P(x, y)=\left(\frac{1}{N_{w}}\right) \sum_{i=1}^{N_{w}} n_{i} \\
n_{i}=\left\{\begin{array}{lr}
1, & \operatorname{if}\left[D_{i}(x, y) \geq \text { dose limit |release }\right] \\
0, & \text { other }
\end{array}\right.
\end{gathered}
$$

$\mathrm{i}$ is the index for simulation step corresponds to a wind profile data. For each simulation step, a dose map is created using the process flow in Figure 1 based on the source term for the same step. The overall number of wind profile $\mathrm{N}_{\mathrm{w}}$ is equal to the number of simulation run. Each simulation is independent from each other. The probability map describes the upper limit of dose received when the release parameter is assumed to be the maximum-release or worstcase scenario.

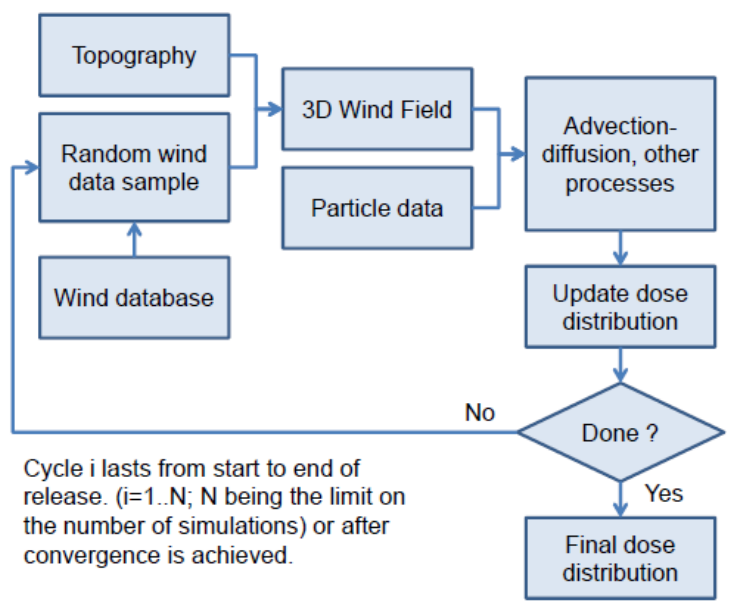

Figure 1. Process flow.

In this paper, simulations are performed using source-term for isotopes of Cs-137, I131, $\mathrm{Kr}-88$, and $\mathrm{Xe}-133$ each with a total strength of $0.011,15.04,62,000$, and 8.37 million Curies [6]. The plume is released at a constant rate for seconds 8,500 to 30,000 after the onset of the accident with the rate specified in Table 1.

\section{RESULT AND DISCUSSIONS}

The Description of wind conditions can be taken from meteorological tower data at 10 meter height during the studied period as follows. Wind direction is distributed unevenly into all 16 sectors with wind blowing with the highest frequency of $14.7 \%$ from the SouthSoutheast in 2014 and $20.9 \%$ from the Southeast direction for 2015. The dominant wind speed is in $2.1-3.6 \mathrm{~m} / \mathrm{s}$ class each having a frequency of $58 \%$ and $62.8 \%$ for 2014 and 2015 respectively. There is no occurrence of calm wind condition at 10 meters for both years. Average wind speeds at 10 meter level are $2.43 \mathrm{~m} / \mathrm{s}$ and $2.35 \mathrm{~m} / \mathrm{s}$ for 2014 and 2015 respectively. Windrose plots for the monitoring period for 2014 and 2015 are given in Figures 2(a) and 2(b) respectively. The colors in the windrose plot represent the classes of wind speed while the angle of the bars represent the direction from which the wind is blowing. Zero degree is North and the direction rotates clockwise. 


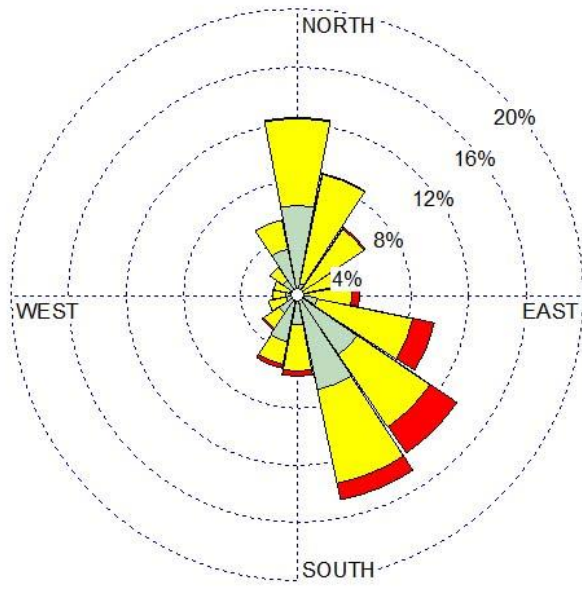

(a)

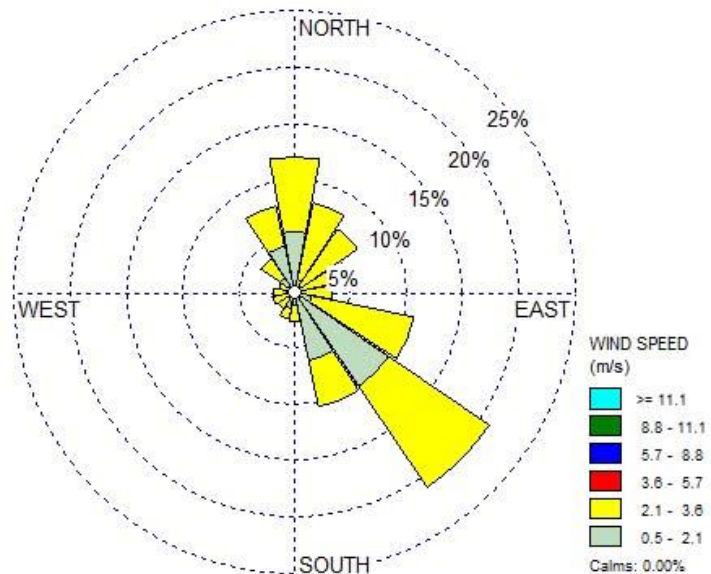

(b)

Figure 2. Windrose in Muntok for 2014(a) and 2015(b).

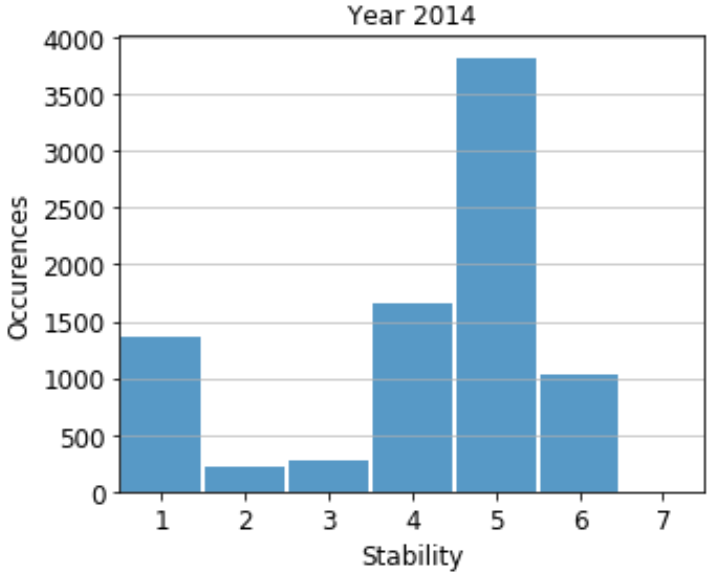

(a)

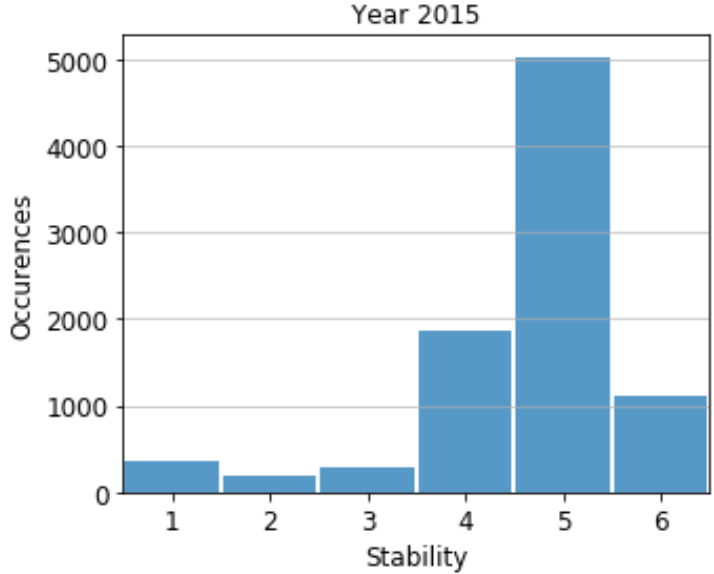

(b)

Figure 3. Atmospheric Stability in Muntok for 2014(a) and 2015(b).

Atmospheric condition during the same period is given in Figures 3(a) and 3(b) for year 2014 and 2015 respectively (class $A=1$ class $\mathrm{F}=6$ ). The data shows that stability is dominated by neutral (D) to stable condition (F) signifying less turbulent condition with an exception in 2014 when there are quite a large proportion of highly unstable condition when intense mixing occurs in the atmosphere. In stable condition, pollutant will be diffused more slowly compared to unstable condition.

The result of the simulation with 100 samples of meteorological condition shows that a large part of radioactive plume is carried away from the release point to the ocean direction (NW-NNW) and some part are dispersed inland (S). The highest dose calculated is $4.35 \mathrm{mSv}$ in sequence number 72 in the simulation and is located within approximately $1 \mathrm{~km}$ radius from release point. The maximum dose exceeded the regulatory limit of $1 \mathrm{mSv}$ for general public in one year set by the regulatory body [18].

Figure 4 and Figure 6 provided the spatial and frequency distribution for individual dose of $1 \mathrm{mSv}$ or more. This magnitude of exposure occurred at mostly uninhabited area with brushes and some farming area.

The result is also presented for a dose limit of $\geq 0.001 \mathrm{mSv}$ in Figure 5. It is apparent that on land the radioactive plume tends to be spread from the plant to NW direction and to $\mathrm{S}$ 
direction from the release point, consistent with the wind distribution pattern at $10 \mathrm{~m}$ provided in Figure 2 for the 2014-2015 monitoring period. The areas most likely to receive $0.001 \mathrm{mSv}$ or more by an incident in this wind condition are Air Putih village and the villages along the shore to the north and the south of the release point. Because the wind tends to blow to the South, the coastal area to the south of the release point will be most affected, up to the Muntok port located at the southern tip of the island. The areas near the release point up to a radius of $5 \mathrm{~km}$ are mostly uninhabited areas except for some fishing and farming activities including palm oil plantations. There are abandoned tin mining areas scattered around the release point but the activity has been banned by the local government and there are no mining activities.

Another center of activity affected by the $0.001 \mathrm{mSv}(1 \mu \mathrm{Sv})$ dose limit is the Muntok Port area in Tanjung Kelian with a probability of between 30-40\%. This port connects Bangka Island with South Sumatra Province. In the case of larger amount of radioactive release or in the presence of wet deposition, the magnitude of dose received may be higher, extended to farther areas and may exceed the regulatory limit depending on the extent of the rain. However, the direction of the dispersion will likely be similar to the dry condition following the same dispersion pattern.

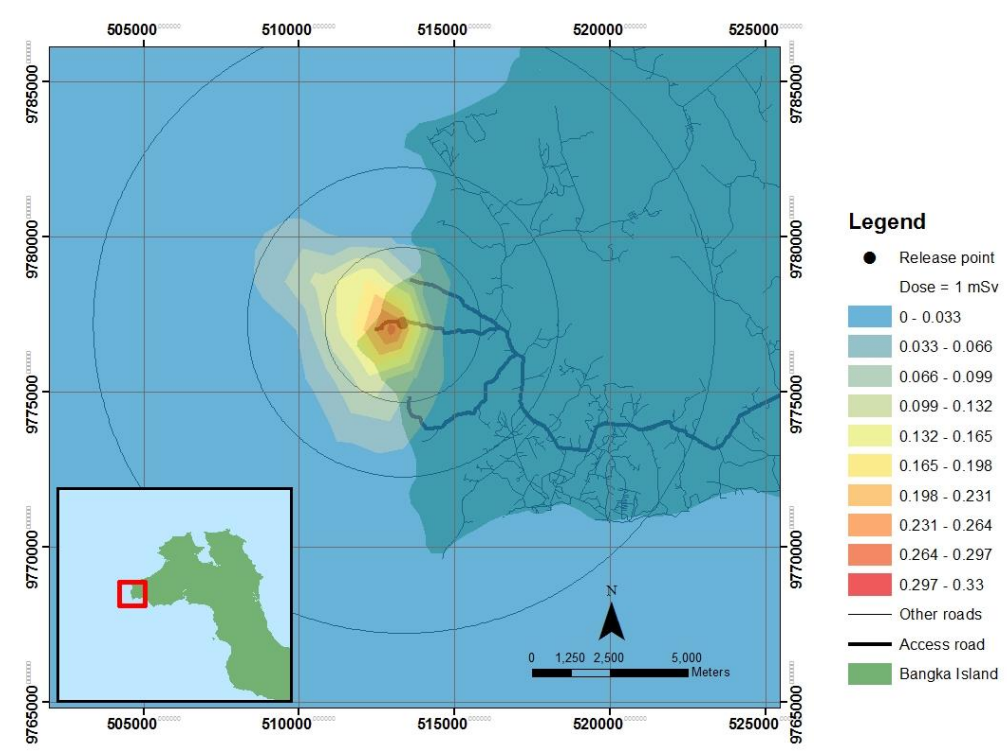

Figure 4. Dose Distribution Probability $\left(\geq_{1} \mathrm{mSv}\right)$.

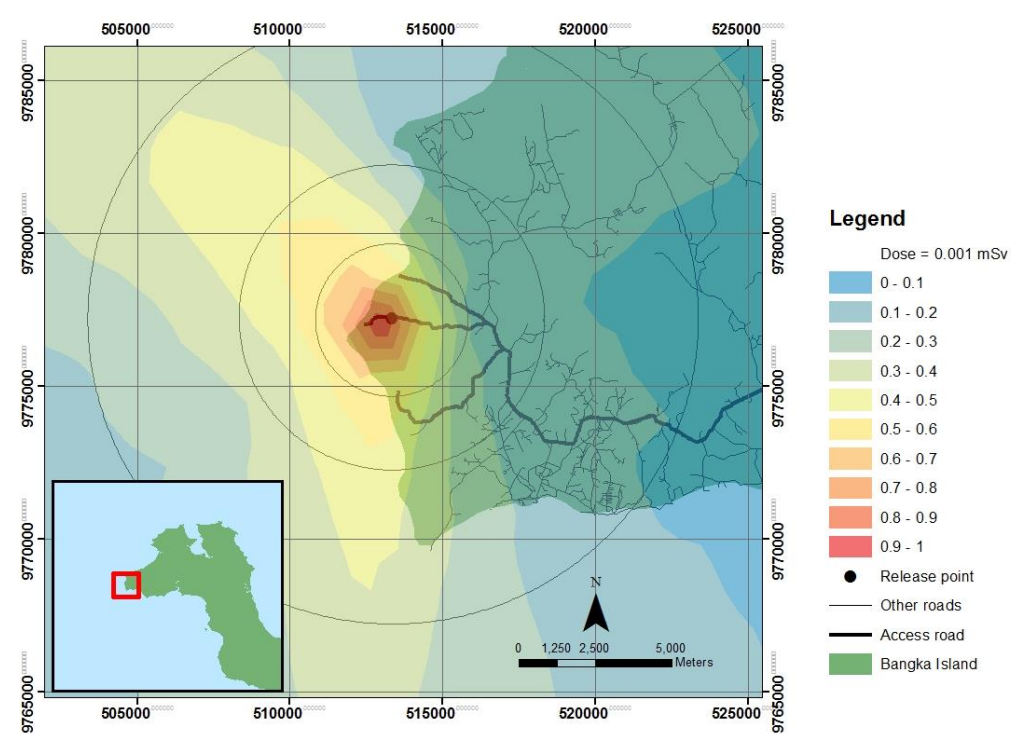

Figure 5. Dose Distribution Probability ( $\geq 0.001 \mathrm{mSv}$ ). 

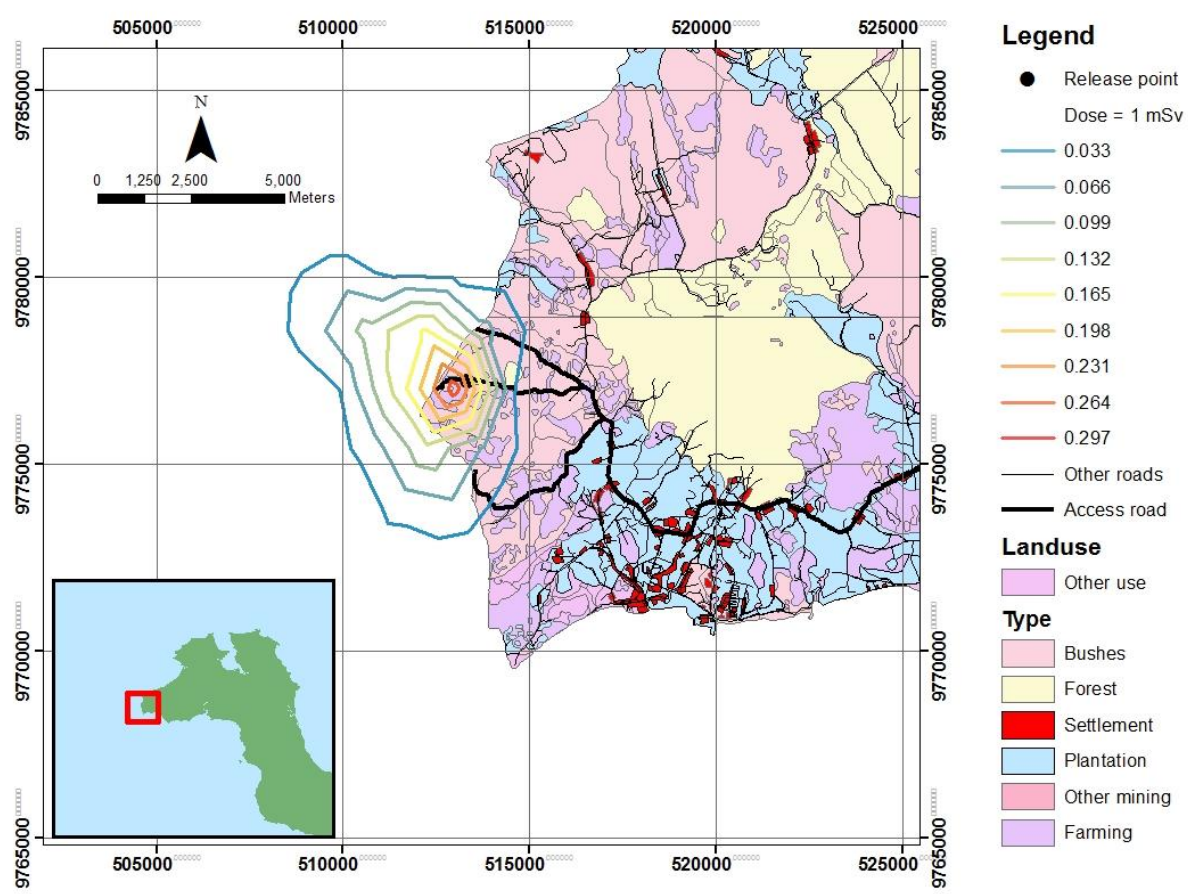

Figure 6. Dose Distribution and Land-Use ( $\geq 1 \mathrm{mSv})$.

According to the West Bangka in Figures[19], the population of Muntok in 2014 is 51,251 people with a density of 101.28 people $/ \mathrm{km}^{2}$ in 2014. The Population growth rate is $2.79 \%$. This number is spread almost in equal proportions among sex and age groups. The main product Muntok district is palm-oil and rubber plantation areas of $1,415.98$ ha and 552.03 ha respectively each producing $1,159.28$ tons and 742.9 tons respectively. The forest area covers 19,509.35 ha and production forest covers 9,398.53 ha. The total area of Muntok district itself is $505.95 \mathrm{~km}^{2}$ or $5,059.5$ ha.

In order to mitigate the effect from larger scale accident, shelters and evacuation routes can be prepared, if they are not readily available, from the shore part of the affected villages to the main road connecting Muntok City to the capital city of Pangkalpinang in the east. Radiation monitoring stations can be located in the areas with high dose potential and early warning system should be in place to provide early warning in case of nuclear emergencies, particularly those located to the south of the facility.

At the populated area of Muntok which is located between 5 to $10 \mathrm{~km}$ from the assumed release point, there is only a very small probability that the public will receive an individual dose of $\geq 1 \mathrm{mSv}$ as can be observed from Figure 7. There is about 50\% of chance that an individual in this area will receive a very low dose of 1 microsievert in this area. This dose is very small and is very unlikely to cause health problem to individuals living in the area.

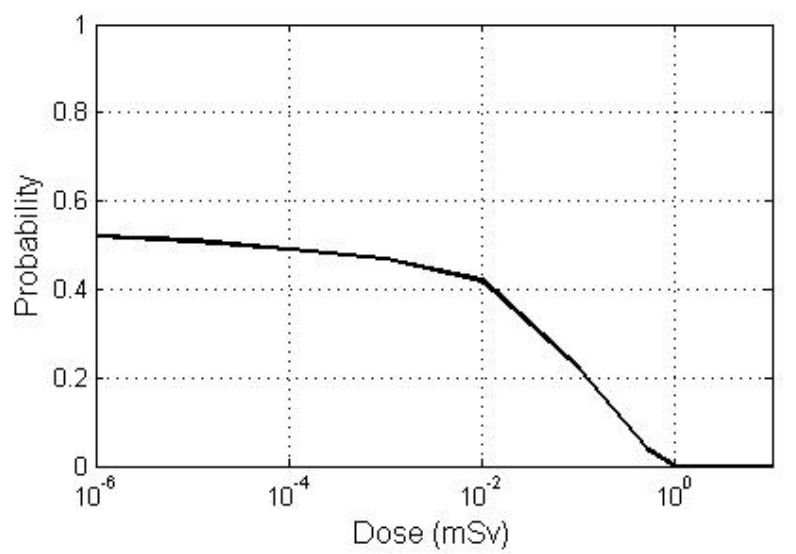

Figure 7. Dose Probability in Muntok City.

In previous study[14], based on a deterministic analysis for LOCA accident using different source-term, the emergency planning zones for West Bangka site have been formulated and are provided in Table 5. The analysis was performed using three accident scenarios and the recorded maximum dose was from NPP-3 accident scenario of $3.24 \mathrm{~Sv}$ at radius $0.8 \mathrm{~km}$ from the release point. 
Table 6. Generic Action Level of Dose for Acute Exposure, by Organ or Tissue [20]

\begin{tabular}{lc}
\multicolumn{1}{c}{ Organ or tissue } & $\begin{array}{r}\text { Action level of dose: Projected absorbed } \\
\text { dose to the organ or tissue in less than } 2 \text { days } \\
(\mathrm{Sv})\end{array}$ \\
\hline Whole body (bone marrow) & 1 \\
Lung & 6 \\
Skin & 3 \\
Thyroid & 5 \\
Lens of the eye & 2 \\
Gonads & 3 \\
\hline
\end{tabular}

This effective dose exceeds Generic Action Level of $1 \mathrm{~Sv}$ given in Table 6. The Precautionary Action Zone (PAZ) area covers up to radius $5 \mathrm{~km}$ where the dose contribution is $0.34 \mathrm{~Sv}$. PAZ is an area where urgent protective action is arranged in the event of nuclear emergency to reduce the risk of severe deterministic health effects. This protective action is taken before or shortly after a release of radioactive material or an exposure based on the prevailing condition given in Table 7 .

UPZ is an area which countermeasures to avert dose have to be taken. Protective actions for UPZ include iodine blocking, sheltering and evacuation. Determination of UPZ area is conducted based on urgent protective action level as given in Table 7 .

The Long term protective action zone is an area where contamination level in the foodstuff and agricultural product should be limited and controlled. The form of protective action can be permanent relocation and food ban. The intervention level for relocation is 100 $\mathrm{mSv} / \mathrm{year}]$ and generic action level for foodstuff is provided in Table III-1 of the
General Safety Requirement IAEA Safety Standard Series [20].

In the event of an accident, evacuation can be performed to the North and East direction of the plant for areas near the plant and to the East for the city of Muntok through a two-lane road. When an accident happens, the people inside the $5 \mathrm{~km}$ radius in the PAZ area should be evacuated. The main road connecting Muntok to other regions in Bangka Island is located at the Southern part of the Island, from the Muntok Port to the capital city of Pangkalpinang. Population projection up to year 2025 indicates that there will be about 1,120 people living inside the $5 \mathrm{~km}$ boundary in the PAZ area. One possible shelter for evacuees is Muntok Vocational School located about $24 \mathrm{~km}$ from the PAZ. In normal traffic condition, this distance can be reached in about 24 minutes, assuming that the average traveling speed of evacuation vehicle of 60 $\mathrm{km} /$ hour. With an average load of 30 people per bus in the evacuation, approximately 38 buses will be required.

Table 7. Generic Criteria for Protective Actions and Other Response Actions in Emergency Exposure Situations to Reduce the Risk of Stochastic Effects [21].

\begin{tabular}{|c|c|c|}
\hline \multicolumn{3}{|c|}{ Examples of protective actions and other response actions } \\
\hline \multirow{2}{*}{\multicolumn{3}{|c|}{ Projected dose that exceeds the following generic criteria: }} \\
\hline & & \\
\hline$H_{\text {Thyroid }}$ & $50 \mathrm{mSv}$ in the first 7 days & Iodine thyroid blocking \\
\hline E & $100 \mathrm{mSv}$ in the first 7 days & \multirow{2}{*}{$\begin{array}{l}\text { Sheltering; evacuation; decontamination; } \\
\text { restriction of consumption of food, milk and water; } \\
\text { contamination control; public reassurance }\end{array}$} \\
\hline \multirow[t]{2}{*}{$H_{\text {Fetus }}$} & $100 \mathrm{mSv}$ in the first 7 days & \\
\hline & \multicolumn{2}{|c|}{$\begin{array}{l}\text { contamination control; public reassurance } \\
\text { Projected dose that exceeds the following generic criteria: }\end{array}$} \\
\hline$E$ & 100 mSv per annum & Temporary relocation; decontamination; \\
\hline$H_{\text {Fetus }}$ & $\begin{array}{l}100 \mathrm{mSv} \text { for the full period of in } \\
\text { utero development }\end{array}$ & $\begin{array}{l}\text { replacement of food, milk and water; public } \\
\text { reassurance }\end{array}$ \\
\hline Dose that has been received and that exceeds the following generic criteria: & Take longer term medical actions to detect and to effectively treat radiation induced health effects & $\begin{array}{l}\text { ceeds the following generic criteria: } \\
\text { effectively treat radiation induced health effects }\end{array}$ \\
\hline E & $100 \mathrm{mSv}$ in a month & $\begin{array}{l}\text { Screening based on equivalent doses to specific } \\
\text { radiosensitive organs (as a basis for medical } \\
\text { follow-up); counseling }\end{array}$ \\
\hline$H_{\text {Fetus }}$ & $\begin{array}{l}100 \mathrm{mSv} \text { for the full period of in } \\
\text { utero development }\end{array}$ & $\begin{array}{l}\text { Counseling to allow informed decisions to be made } \\
\text { in individual circumstances }\end{array}$ \\
\hline
\end{tabular}




\section{CONCLUSIONS}

Probabilistic analysis using upper limit scenario has been applied to make individual radiation dose equivalent prediction for a dry condition case in Muntok city, West Bangka Regency, using source-term parameters compiled from literatures on Three-Mile Island NPP accident in the USA. The meteorological data used in the analysis is obtained from onsite monitoring in Muntok, West Bangka Regency.

Calculated maximum individual effective dose from the TMI-2 accident scenario and taking into consideration the local atmospheric condition is $4.35 \mathrm{mSv}$. The Regulatory limit for general public of $1 \mathrm{mSv}$ is exceeded in area within the $2.5 \mathrm{~km}$ radius from release point in uninhabited area consisted of bushes and farming areas. Evacuation is necessary for the PAZ, especially for those living inside the $1 \mathrm{~km}$ boundary. At the highly populated area in the city of Muntok, located about $7.2 \mathrm{~km}$ to the Southeast, the probability for individual effective dose exceeding the regulatory limit of $1 \mathrm{mSv}$ is less than $6.6 \%$ and therefore sheltering, requiring the public to stay indoors, maybe in order but evacuation may not be necessary. In case of evacuation, moving the inhabitant to the East toward Pangkalpinang is more preferable to moving out from the Muntok port to the South Sumatran side because of the high frequency of wind blowing to the South. Therefore, road infrastructure needs to be further assessed to enable safe and smooth evacuation when necessary.

Considering the dispersion pattern given by the $\geq 0.001 \mathrm{mSv}$ dose limit, the villages along the shore to the west of Muntok site are more likely to be affected than other areas, although the amount of dose received will be lower than the dose limit for general public set by Indonesian nuclear regulatory body (BAPETEN) for this accident scenario.

\section{REFERENCES}

[1]. Uliasz, M.. 1994. Lagrangian Particle Dispersion Modeling in Meso-scale Applications. Environmental Modelling II. ed. P. Zannetti, Computational Mechanics Publication, Southampton, Boston, 71.
[2]. Ermak D. R., Nasstrom J. S. and Taylor A.G., "Implementation of random displacement method in the adipic model framework". Report no UCRL-ID121742, Livermore: Lawrence Livermore National Laboratory pp 1-16, 1995.

[3]. Haste T., Birchley J., Cazzoli E. and Vitazkova J., 2006, "MELCOR/MACCS Simulation of the TMI-2 Severe Accident and Initial Recovery Phases. Offsite Fission Product Release and Consequence", Nucl. Eng. and Des.,Vol. 236, p. 1099.

[4]. Gudiksen P. H. and Dickerson M. H.,"A review of source-term and dose estimation for the TMI-2 reactor accident". Lawrence Livermore National Laboratory Report UCRL-JC-104077, Livermore: Lawrence Livermore National Laboratory, pp 1-17, 1990.

[5]. United States Nuclear Regulatory Committee, NRC views and analysis of the recommendations of the President's commission on the accident at three mile island. Tech. Rep. NUREG-0632, USA, 1979.

[6]. McCOLL N. P. and Prosser S. L., Emergency Data Handbook National Radiological Protection Board NRPB-W19. Oxon: National Radiological Protection Board), pp 1-69, 2002.

[7]. Sunarko, Zaki Su'ud, Idam Arif, Syeilendra Pramuditya, 2017, Probabilistic Dose Assessment from SB-LOCA Accident in Ujung Lemahabang Using TMI-2 Source Term, Science and Technology of Nuclear Installations, Vol. 2017, pp. $1-8$.

[8]. Final Topical Report - Year 2 Dispersion and Dose Assessment, PT. SURVEYOR INDONESIA, Jakarta, 2012.

[9]. Diehl S. R., Smith, D. T. And Sydor M., "Randomwalk simulation of gradient-transfer processes applied to dispersion of stack emission from coalfired power plants", J. of Appl. Meteo. 21 69, 1982.

[10]. Seinfeld J. H. 1986. Atmospheric Chemistry and Physics of Air Pollution ( $1^{\text {st }}$ Edition), Wiley Interscience, 768.

[11]. U.S. Environmental Protection Agency, Meteorological monitoring guidance for regulatory modeling applications. Tech.Rep. EPA-454/R-9900, 2000.

[12]. Sherman C. A., "A mass-consistent model for wind fields over complex terrain”, J. of Appl. Meteo., Vol. 17, p. 312. 1977.

[13]. Sunarko, Su'ud, Z., "Radiological dose in Muria Peninsula from SB-LOCA event”, IOP Conf. Series: Journal of Physics: Conf. Series 799, 2017.

[14]. Final Topical Report - Year 2 Emergency Preparedness. PT. SURVEYOR INDONESIA Jakarta, 2012.

[15]. Sunarko. 2009. "Model dispersi partikel untuk perhitungan lepasan radioaktif (Studi kasus semenanjung Muria-Jawa Tengah)”, MasterThesis, Institut Teknologi Bandung, Bandung.

[16]. Lam H. Y., Li S. W. And Yeung P. Y.. 2005. "A random-walk particle dispersion model for radiological accident consequence assessment", Technical Note (Local) No 82 (Hong Kong: Hong Kong Observatory) pp 1-45.

[17]. Bonadonna C., "Probabilistic modeling of tephra dispersal: Hazard assessment of a multiphase rhyolitic eruption at Tarawera New Zealand, Journal of Geophysical Research 110, No. 1, 2005. 
[18]. BAPETEN, Peraturan Kepala Badan Pengawas Tenaga Nuklir Nomor 4 Tahun 2013: Proteksi dan Keselamatan Radiasi Dalam Pemanfaatan Tenaga Nuklir, Badan Pengawas Tenaga Nuklir, Jakarta, 2013..

[19]. Bangka Barat dalam Angka, BPS Bangka Barat, Muntok, 2015.

[20]. IAEA-Safety Standard Series No. GS-R-2: Preparedness and Response for a Nuclear or Radiological Emergency, International Atomic Energy Agency, Vienna, 2002.

[21]. IAEA-Safety Standard Series No. GSG-2: Criteria for Use in Preparedness and Response for a Nuclear or Radiological Emergency, International Atomic Energy Agency, 2011. 
HALAMAN INI SENGAJA DIKOSONGKAN 